\title{
BIBLIOGRAPHIC NEWSLLTTER
}

Below is a list of recent publications by faculty, graduate students, and former students of the Department of Linguistics, University of Colorado.

\section{Faculty}

\section{Alan E. Bell}

National Science Foundation support of linguistic research. Linguistic Reporter 16:3.1-10 (1974).

Frede Jensen

The Syntax of the 01d French Subjunctive. The Hague: Mouton and Company $(1974)$.

Diachronic hypercharacterization of gender in the old Provencal adjective. Semasia 1.7-20 (1974).

Provençal cor and cors: a flexional dilema. Romance Philology 28.27-31 (1974).

Retour sur la flexion du provençal coms-comte. Zeitschrift für romanische Philologie 90.497-8 (1974).

John T. Jensen

A constraint on variables in phonology. Language 50.675-86 (1974).

\section{David S. Rood}

Wichita verb structure: inflectional categories. In Studies in Southeastern Indian Languages, James M. Crawford, ed. 121-134. Athens: University of Georgia Press (1974).

Review of Herbert Penzl, Methoden der germanischen Linguistik. Sprachstrukturen, Reihe A (Historische Sprachstrukturen), $\mathrm{Nr}$. 1. Tübingen: Max Niemeyer, 1972. Modern Language Journal $58.210-11(1974)$.

Review of Philip W. Dari3, Modern Theories of Language. Englewood Cliffs: Prentice Hall, 1973. Modern Language Journal 58:361-2 (1974).

Luigi Romeo

Classical linguistics. In Historiography of Linguistics, Current Trends, Thomas A. Sebeok, ed. Vol. 13.111-257. The lague: Mouton and Company (1974).

A sociolinguistic view of nedieval romance erotic poetry. Forum Italicum 7-3.81-101 (Dec. 1973-March 1974). 
Students

Akil A. Asfoor Arabic Grammatical Scholarship in the Medieval Period. Boulder (Colorado): Este Es Press $(1974)$.

Claudia w. Corun

Adverbs... long and tangled roots. Papers from the Tenth Regional Meeting. Chicago Linguistic Society, Apri1 19-21, 1974. 30-102.(1974).

Steven N. Sheldon

Some morphophonemic and tone perturbation rules in

Mura-Pirahã. International Journal of American Linguistics 40.279-282 (1974).

Margaret Stcng-Jensen

Two Conditions in Phonology. Orange Papers: Syracuse

Studies in Linguistics, Vol. 1, No. 1. Syracuse, N.Y.:

The Linguistics Association of Syracuse Foundation, Inc.

(1973). 